\title{
Pengembangan Buku Ajar Perkoperasian Indonesia Dalam Perkuliahan Mahasiswa Prodi Pendidikan Ekonomi
}

\author{
Putri Vina Sefaverdiana ${ }^{1}$, Melisa Wahyu Fandyansari² \\ Prodi Pendidikan Ekonomi IKIP Budi Utomo \\ email: viseverputri@gmail.com
}

Received: 20 Nopember, 2020; Accepted: 11 Desember 2020; Published: 17 Desember, 2020

\begin{abstract}
Abstrak
Buku ajar Perkoperasian Indonesia merupakan penelitian pengembangan yang bertujuan mengembangkan buku ajar yang berkualitas dan secara efektif dapat meningkatkan pemahaman akan koperasi yang ada di Indonesia. Buku ajar sebagai penunjang dalam perkuliahan Perkoperasian, guna meningkatkan pembelajaran mahasiswa dalam kelas sehingga mahasiswa memiliki pemahaman dan ketrampilan dalam berkoperasi. Tujuan buku ajar ini untuk memudahkan mahasiswa dalam mempelajari dan memahami sebagai bekal mahasiswa dalam mengembangkan koperasi di daerah tempat tinggal masing-masing. Metode dalam penelitian ini adalah penelitian pengembangan Research And Development dengan menggunakan model dari Dick and Carrey. Hasil uji yang telah diperoleh dari ahli materi pertama yaitu $84,5 \%$, ahli materi kedua memperoleh $76,4 \%$ Ahli berikutnya yaitu ahli media dimana memperoleh hasil $79,2 \%$ dan yang terakhir validator ahli bahasa, dimana dari ahli bahasa memperoleh hasil $82,3 \%$. Setelah uji ahli dilaksanakan uji skala kecil dimana memperoleh hasil 82,6\% dan uji skala besar memperoleh hasil 86,3\%. Dari hasil presentase tersebut menyatakan bahwa buku ajar masuk kategori baik dan layak untuk diterapkan.
\end{abstract}

Kata kunci: Buku Ajar; Perkoperasian Indonesia.

\begin{abstract}
Indonesian Cooperative textbooks are development research aimed at developing quality textbooks and can effectively improve understanding of existing cooperatives in Indonesia. Textbooks as a support in Cooperative lectures, in order to improve student learning in class so that students have understanding and skills in cooperating. The purpose of this textbook is to make it easier for students to learn and understand as a provision for students to develop cooperatives in their respective areas of residence. The method in this research is a research and development research using a model from Dick and Carrey. The test results obtained from the first material expert were $84.5 \%$, the second material expert obtained $76.4 \%$. 3\%. After the expert test was carried out a small-scale test where the result was $82.6 \%$ and the large-scale test obtained a result of $86.3 \%$. From the results of the percentage, it states that the textbook is in the good category and is feasible to apply
\end{abstract}

Keywords: Textbook; Indonesian Cooperatives. 


\section{PENDAHULUAN}

Pendidikan di zaman sekarang sangatlah penting, dimana tidak hanya mengangkat status sosial keluarga melainkan juga memberikan pembelajaran, pengalaman dan kemampuan setiap orang dalam berinteraksi dan menempatkan diri untuk mampu hidup bermasyarakat. Secara konvensional maupun inovatif peningkatan kualitas suatu pendidikan akan terus dilakukan. Dalam UU No. 20, Tahun 2003 pasal 3 menjelaskan bahwa tujuan pendidikan adalah mengembangkan potensi peserta didik menjadi manusia yang beriman dan bertaqwa kepada Tuhan, cakap, mandiri, serta menjadi warga Negara yang demokratis dan tanggung jawab. Basuki (2012) menyatakan bahwa pendidikan karakter dapat diintegrasikan dalam pembelajaran pada setiap mata kuliah yang berkaitan dengan norma atau nilai nilai yang dikembangkan, dieksplisitkan, dikaitkan, dalam konteks kehidupan sehari - hari. Dengan demikian pembelajaran karakter tidak hanya menyentuh pada tataran kognitif, tetapi menyentuh pada internal dan pengalaman nyata peserta didik di kehidupan sehari - hari.

Buku ajar Perkoperasian Indonesia masih sangat minim dan belum terdapat penjelasan secara terperinci, dimana hanya teori dan belum menunjukkan ada nya praktek sebagai bekal mahasiswa jika nantinya sudah lulus. Buku ajar merupakan bagian penting dalam proses pembelajaran. Buku ajar dijadikan sebagai salah satu sumber informasi materi yang penting bagi guru maupun siswa. Buku ajar merupakan buku teks yang dipakai sebagai rujukan pada mata pelajaran tertentu (Akbar, 2013:33). Hal serupa dikemukakan (Prastowo, 2014:117), yang menyatakan bahwa buku ajar adalah buku yang berisi ilmu pengetahuan dan disusun berdasarkan kompetensi dasar yang ada dalam kurikulum tertentu serta digunakan oleh siswa untuk belajar. Sebuah buku pelajaran merupakan teknologi pendidikan yang sangat menguntungkan diantaranya: 1) pegangan seorang guru menentukan metode pembelajaran, 2) menyesuaikan kurikulum, 3) memudahkan peserta didik untuk mengulangi pembelajaran maupun mempelajari materi baru (Nasution, 2005:103).

Keberadaan buku ajar dapat membantu guru dalam mencapai tujuan pembelajaran. Didukung dengan pernyataan bahwa penggunaan buku teks berbasis JPEK, Vol. 4, No. 2 Desember 2020. 244 
kontekstual mampu meningkatkan aktivitas dan hasil belajar siswa (Metalin et al., 2016). Sementara itu, (Majid, 2008:140) menyatakan bahwa buku ajar yang baik yaitu buku yang memiliki tiga ciri, yaitu (1) menggunakan bahasa yang baik dan mudah dipahami; (2) penyajian bukunya menarik, dilengkapi dengan gambar, dan dilengkapi dengan keterangan; (3) isi buku menggambarkan ide penulisnya. Saat ini buku ajar yang digunakan oleh guru dalam pembelajaran memerhatikan kondisi siswa dan lingkungannya (belum kontekstual) karena pada umumnya guru hanya memanfaatkan buku teks terbitan pemerintah sebagai pegangan dalam pembelajaran.

Di era sekarang ini calon lulusan perguruan tinggi mau tidak mau dituntut menjadi lulusan dengan memiliki kemampuan dan ketrampilan sesuai dengan dunia kerja, dimana mahasiswa tidak hanya belajar dan menguasai materi melainkan bagaimana cara penguasaan ketrampilan yang relevan khususnya di bidang ekonomi. Sesuai dengan pengalaman peneliti dalam mengajar mata kuliah Perkoperasian terdapat kendala dalam pembelajaran, antara lain pelajaran Koperasi pada umunya diperoleh sejak duduk di bangku SD, SMP maupun SMA tapi kenyataannya masih banyak mahasiswa yang belum paham tentang koperasi, permodalan, pembentukan, pembubaran, jenis dan bagaimana cara pembagian SHU. Mahasiswa pendidikan ekonomi IKIP Budi Utomo diharapkan tidak hanya focus menjadi tenaga pendidik (guru) melainkan nantinya mampu mengembangkan dirinya maupun daerahnya dalam berkoperasi sehingga dapat membangun daerah masing-masing dengan mempraktekkan secara langsung mendirikan sebuah koperasi dengan maksud membantu masyarakat sekitar maupun memberikan pelatihan bagaimana cara berkoperasi, sesuai dengan asas koperasi yaitu kekeluargaan dan gotong royong.

Mata kuliah Perkoperasian adalah mata kuliah wajib di Prodi Pendidikan Ekonomi IKIP Budi Utomo Malang dimana Koperasi merupakan bagian penting dalam perekonomian, hal ini diketahui bahwa dalam pelaksanaanya koperasi mengutamakan kepentingan bersama dan untuk para anggotanya. Koperasi sebagai wadah dalam kegiatan pemenuhan kebutuhan sehingga masyarakat dapat terbantu dengan adanya koperasi. Asas kekeluargaan dan saling membantu sebagai wujud JPEK, Vol. 4, No. 2 Desember 2020. 245 
mensejahterakan masyarakat sekitar dimana masyarakat dipermudah untuk memenuhi kebutuhannya sesuai dengan prinsip koperasi. Pertumbuhan koperasi perlu diperhatikan dan dikembangkan karena dengan adanya koperasi dapat memperbaiki ekonomi terbatas serta membantu untuk memenuhi kebutuhan seharihari. Sesuai dengan dengan pendapat Internasional Labour Organization (ILO dalam Tambunan and Tambunan, 2019:7) bahwa koperasi adalah sekumpulan orang yang mempunyai tujuan tertentu secara sukarela bergabung untuk meningkatkan taraf hidup melalui pembentukan koperasi yang dikelola secara demokratis, dibuat secara adil pada pemodalan, serta penerimaan yang adil dari resiko dan manfaat usaha.

Besar harapan setelah mahasiswa lulus dapat mengaplikasikan ilmu mereka di lingkungan sekitar untuk membantu masyarakat dalam memenuhi kebutuhan serta membantu mensejahterakan masyarakat. Koperasi yang ada sekarang masih perlu diperbaiki dan dikembangkan, seperti bagaimana cara kerja koperasi harus disesuaikan dengan prinsip koperasi yaitu berasaskan kekeluargaan dan gotong royong. Perlu adanya pelatihan-pelatihan untuk dapat mengembangkan koperasi di jaman yang sudah maju seperti sekarang, jangan sampai sebagai anak muda penerus bangsa tidak mampu menjaga keutuhan koperasi. Beberapa koperasi sekarang tidak berdasarkan asas tapi lebih mementingkan keuntungan pribadi. Besar harapan dengan adanya buku ajar ini mampu membuka pikiran anak-anak muda untuk lebih paham dan mengerti akan koperasi.

\section{METODE}

Jenis penelitian yang digunakan dalam penelitian ini adalah penelitian pengembangan (Research and Development) (Sugiyono, 2011). Penggunaan metode Research and Development dalam penelitian ini bermaksud untuk mengembangkan buku ajar pada mata kuliah Perkoperasian di IKIP Budi Utomo Malang. Penelitian dilakukan kepada mahasiswa pendidikan Ekonomi IKIP Budi Utomo Malang, yang berada di Jl, Citandui no 46 Malang. Pengumpulan data dalam penelitian ini menggunakan angket, baik angket dari para ahli atau validator buku 
ajar, yaitu validator ahli materi koperasi pertama, validator ahli materi koperasi kedua, validator ahli media, dan validator ahli bahasa maupun uji mahasiswa.

Penelitian ini dirancang dengan menggunakan model instruksional Dick and Carey. Model instruksional Dick and Carey terdapat 10 langkah atau tahapan namun dalam penelitian ini hanya menggunakan 9 tahapan saja, yaitu : 1) mengidentifikasi tujuan perkuliahan umum, 2) mengenali masukan karateristik dan ciri mahasisa peserta matakuliah perkoperasian, 3) melakukan analisis materi matakuliah perkoperasian, 4) merumuskan tujuan khusus dari matakuliah perkoperasian, 5) mengembangkan butir tes acuan pada buku ajar, 6) mengembangkan strategi iinstruksional, 7) mengembangkan dan menulis sumber alat dan media instruksional buku ajar, 8) merancang dan melakukan evaluasi formatif, dan 9) merancang dan melaksanakan evaluasi sumatif.

Rancangan yang digunakan selama penelitian dijabarkan pada gambar di bawah ini:

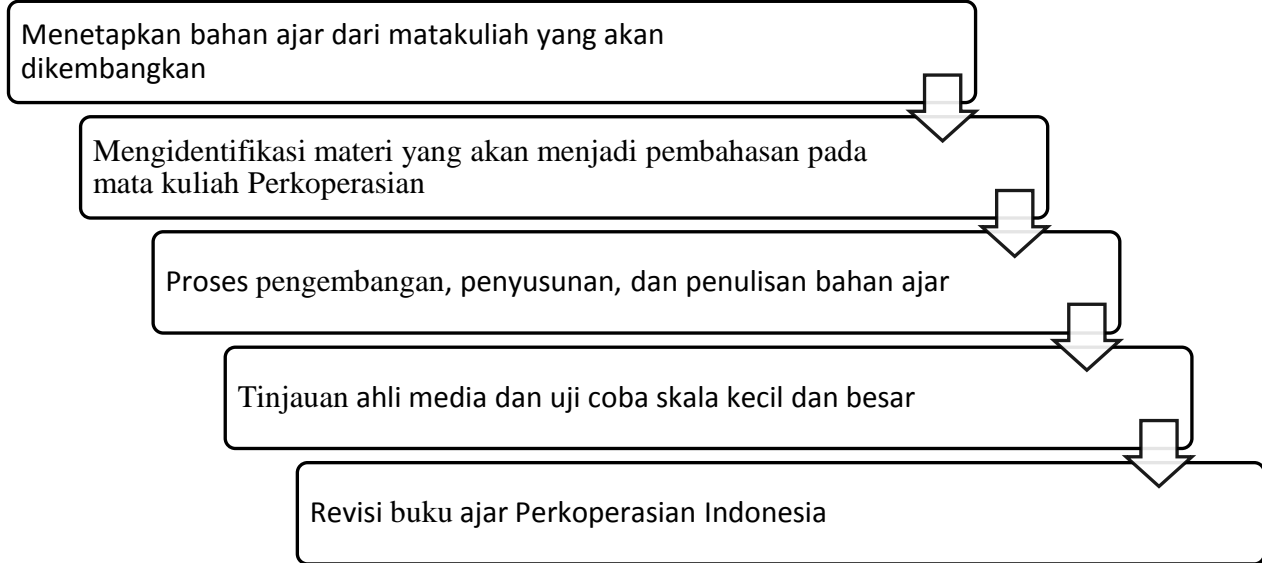

Gambar 1. Rancangan Penelitian

Kegiatan pengembangan atau penyusunan buku ajar Perkoperasian Indonesia ini, melalui 5 tahapan seperti yang telah tergambar di atas, yaitu

1. Menetapkan bahan ajar dari matakuliah yang akan dikembangkan. Pada tahap ini, peneliti perlu menetapkan matakuliah apa yang akan dikembangkan oleh peneliti, yang akan digunakan sebagai buku ajar pada mahasiswa Prodi Pendidikan Ekonomi. Penetapan didasarkan pada beberapa alasan, yaitu belum tersedianya buku Perkoperasian yang sesuai dengan mahasiswa Pendidikan Ekonomi IKIP Budi Utomo. 
2. Mengidentifikasi materi yang menjadi pembahasan pada matakuliah Perkoperasian. Setelah menentukan matakuliah yang akan dipilih untuk membuat buku ajar, langkah selanjutnya adalah menetapkan isi atau materi dari Perkoperasian.

3. Proses pengembangan, penyusunan dan penulisan buku ajar. Pada tahap ini ada tujuh. langkah yang akan dilakukan, yaitu: (a) mengidentifikasi tujuan pembelajaran, (b) menganalisis tujuan pembelajaran, (c) mengidentifikasi perilaku dan karakteristik mahasiswa, (d) mendesain indikator capaian, (e) mengembangkan butir soal, (f) mengembangkan strategi pem-belajaran, (g) mengembangkan buku ajar Perkoperasian

4. Tinjauan ahli dan uji coba. Tahapan ini merupakan suatu proses pengumpulan informasi sebagai dasar guna pengambilan keputusan dalam rangka meningkatkan kualitas produk yang dikembangkan. Tinjauan ahli disusun berdasarkan langkah pengembangan yang terdapat pada buku ajar dan masih berupa draft, yang nantinya akan digunakan untuk pengumpulan data dan penyempurnaan buku ajar lebih lanjut. Dalam pengembangan buku ajar Perkoperasian ini menggunakan tiga tahap kajian atau uji ahli, yaitu: (1) review ahli materi dan ahli rancangan pembelajaran (2) uji coba kelompok kecil atau teman sejawat, serta (3) uji coba lapangan.

5. Revisi buku ajar Perkoperasian. Tahap terakhir ini adalah revisi produk bahan ajar. Hasil yang diperoleh dari uji coba dan review ahli dan uji lapangan, dijadikan dasar dan pedoman dalam perbaikan buku ajar agar dapat diupayakan menjadi buku ajar yang memudahkan pemahaman dan penguasaan mahasiswa terhadap materi Perkoperasian.

Materi yang dibahas dalam buku ajar ada enam bab, yaitu: 1). BAB I Koperasi: a). Pengertian Koperasi, b). Makna Lambang Koperasi, c). Landasan dan Asas Koperasi, d). Fungsi, Peran, dan Prinsip Koperasi, e). Koperasi dan SistemSistem Ekonomi; 2). BAB II Manajemen Koperasi: a). Definisi Manajemen dan Perangkat Koperasi, b). Perencanaan, Pengorganisasian, Pengarahan, Pengkoordinasian, dan Pengendalian, c). Rapat Anggota, Pengurus, Pengawas, dan Manajer, d). Hubungan Kerja Pengurus, Pengawas, dan Manajer; 3). BAB III JPEK, Vol. 4, No. 2 Desember 2020. 248 
Pembentukan dan Pembubaran Koperasi: a). Syarat Pembentukan Koperasi, b). Langkah Pembentukan Koperasi, c). Pengesahan Akta Pendirian Koperasi, d). Pembubaran Koperasi Berdasarkan Rapat Anggota, e). Pembubaran Koperasi Berdasarkan Keputusan Pemerintah; 4). BAB IV Permodalan Koperasi: a). Arti Modal Bagi Koperasi, b). Sumber Modal Koperasi, c). Perbedaan Saham Koperasi dengan Saham PT, d). Dana Cadangan , e). Cara Pembagian Sisa Hasil Usaha; 5). BAB V Bentuk, Jenis dan Perbedaan Koperasi dengan Badan Usaha Lain: a). Bentuk Koperasi, b). Jenis Koperasi, c). Bentuk Badan Usaha, d). Perbedaan Koperasi dengan Usaha Swasta dan Milik Negara, e). Perbedaan Koperasi dengan Gotong Royong; 6). BAB VI Kebijakan Pembangunan Koperasi di Indonesia: a). Kebijakan Pembangunan Koperasi, b). Pembinaan dan Pengembangan Koperasi Unit Desa, c). Revitalisasi Koperasi, d). Akuntabiltas Koperasi.

\section{HASIL PENELITIAN DAN PEMBAHASAN (Capital, Font 12, Bold)}

Data yang diperoleh pada penelitian pengembangan Buku Ajar Perkoperasian Indonesia ini merupakan data hasil validasi dan penilaian yang dilakukan peneliti kepada mahasiswa melalui uji skala. Hasil dari penelitian R\&D metode Dick and Carey yang memiliki sembilan langkah seperti penjelasan di atas. Setelah draft buku ajar selesai dibuat maka berikutnya adalah menguji produk buku tersebut. Dimana uji yang pertama dilakukan adalah uji kepada validator ahli. Dari ahli materi perkoperasian 1, diperoleh hasil uji validator sebesar 84,5\% dan mendapat predikat sesuai atau layak digunakan. Ahli berikutnya adalah ahli materi perkoperasian 2 yang didapat hasil 76,4\% dengan predikat layak dan mendapat saran untuk tata kalimat dalam penjelasan materi diperbaiki. Ahli berikutnya adalah media, yang di dapat angka uji sebesar 79,2\%. Terakhir validator ahli bahasa, dimana dari ahli bahasa didapat hasil uji sebesar 82,3\%.

Setelah melalui tahap uji validasi, maka berikutnya adalah uji produk dengan mahasiswa. Ada dua uji yaitu uji skala kecil dan uji skala besar. Uji skala kecil didapat hasil 82,6\%. Dan uji skala besar didapat nilai 86,3\% dan masingmasing hasil uji masuk dalam kategori atau kualifikasi baik. 


\section{Pembahasan}

Berdasarkan hasil validasi buku ajar oleh validator dengan kualifikasi bidang studi ekonomi diperoleh hasil bahwa buku ajar perkoperasian Indonesia layak atau sudah memenuhi kriteria penilaian baik sebagai penunjang perkuliahan. Nilai tertinggi pada aspek ahli materi dimana mencakup kejelasan indikator dengan isi materi, kejelasan tujuan pembelajaran, kejelasan penyajian materi di buku perkoperasian Indonesia, kelengkapan materi, kesesuaian konsep materi, pengevaluasi materi, kesesuaian soal/tes dan kesesuaian isi materi dengan waktu yang disediakan. Buku ajar perkoperasian Indonesian sangat efektif dan praktis digunakan dalam perkuliahan mahasiswa pendidikan ekonomi, hal ini dikarenakan buku ajar yang dikembangkan dapat meningkatkan kompetensi mahasiswa dalam perkuliahan. Diperkuat dengan pernyataan bahwa sebuah gambar yang berhubungan dengan lingkungan sangat membantu dalam proses belajar mengajar (Sukerni, 2014)

Buku ajar perkoperasian Indonesia mampu menarik antusius mahasiswa dalam pembelajaran, dikarenakan bahasa maupun tatanan isi yang tertuang dalam buku ajar mudah dipahami dan dimengerti sehingga daya serap akan berkoperasi sangatlah mudah dicerna, selain itu terdapat juga latihan soal disetiap bab materi sehingga memudahkan mahasiswa dalam mengasah kemampuan dalam tugas individu maupun kelompok.

Buku ajar yang mudah dipahami dan diingat akan sangat membantu mahasiswa dalam perkuliahan dan mampu meningkatkan rasa ingin tau serta menggali kemampuan berkoperasi yang baik dan mampu mengembangkan koperasi-koperasi yang ada di daerah tempat tinggal atau memberikan pelatihanpelatihan kepada masyarakat agar koperasi yang sudah ada mampu bertahan dan lebih berkembang untuk kepentingan masyarakat. Dari serangkaian langkah yang telah dilakukan, dapat dilihat bahwa buku ajar perkoperasian Indonesia yang dikembangkan telah memenuhi kriteria valid, menarik, praktis dan efektif digunakan dalam pembelajaran. Hal ini didukung dengan pendapat Akker (dalam Sofnidar \& Sabil, 2012) yang menyatakan bahwa kualitas perangkat pembelajaran JPEK, Vol. 4, No. 2 Desember 2020. 250 
setidaknya dilihat dari kriteria kevalidan (validity), kepraktisan (practically), dan keefektifan (effectiveness).(Rohmah, Dina Fitrohtur, Hariyono, 2017)

\section{KESIMPULAN}

Penelitian ini telah menghasilkan suatu produk berupa buku ajar Perkoperasian Indonesa. Buku ajar Perkoperasian Indonesia yang dikembangkan dalam penelitian ini salah satu wujud memenuhi kebutuhan mahasiswa dalam mengembangkan pemahaman dalam berkoperasi. Metode yang digunakan adalah R\&D Dick and Carrey. . Hasil uji yang telah diperoleh dari ahli materi pertama yaitu $84,5 \%$ dengan kategori nilai layak, ahli materi kedua memperoleh 76,4\% dengan kategori nilai layak. Ahli berikutnya yaitu ahli media dimana memperoleh hasil 79,2\% mendapatkan nilai layak dan yang terakhir validator ahli bahasa, dimana dari ahli bahasa memperoleh hasil $82,3 \%$ mendapatkan nilai layak. Uji yang dilakukan oleh mahasiswa diperoleh nilai rata-rata "sangat baik", dimana uji skala kecil memperoleh hasil 82,6\% dan uji skala besar memperoleh hasil 86,3\%. Hal tersebut menunjukkan bahwa buku ajar perkoperasian Indonesia layak digunakan dan dapat dijadikan referensi atau rujukan bagi Mahasiswa Program Studi Pendidikan Ekonomi dalam kegiatan perkuliahan.

\section{DAFTAR RUJUKAN}

Akbar, S. (2013). Instrumen Perangkat Pembelajaran. Bandung :PT Remaja Rosdakarya.

Dick, W. \& Carey, L. (1996). The Systematic Design of Instruction. New York: Harper Collin Publishers.

Majid, A. (2008). Perencanaan Pembelajaran: Mengembangkan Standar Kompetensi Guru Cetakan ke -5. Bandung :PT Remaja Rosdakarya.

Metalin, A., Puspita, I., Djatmika, E. T., Hasanah, M., Dasar, P., \& Malang, P. N. (2016). Peningkatan Hasil Belajar Siswa Berbantuan Buku Teks Berbasis Kontekstual Untuk Siswa Kelas II Sekolah Dasar. Jurnal Pendidikan: Teori, Penelitian Dan Pengembangan, 1(10), 1880-1883.

Nasution, S. (2005). Teknologi Pendidikan. Jakarta :Bumi Aksara.

Prastowo, A. (2014). Pengembangan Bahan Ajar Tematik Tinjauan Teoritis dan

JPEK, Vol. 4, No. 2 Desember 2020. 251 
Praktis. Jakarta :Kencana Prenadamedia Group.

Rohmah, Dina Fitrohtur, Hariyono, S. (2017). Pengembangan Buku Ajar IPS SD Berbasis Kontekstual. Jurnal Pendidikan : Teori, Penelitian Dan Pengembangan, 2(5), 719-723.

Sugiyono. (2011). Metode Penelitian Kuantitatif, Kualitatif, dan $R \& D$. Bandung :Alfabeta.

Sukerni, P. (2014). Pengembangan Buku Ajar Pendidikan IPA Kelas IV Semester I SD No . 4 Kaliuntu Dengan Model Dick and Carey. Jurnal Pendidikan Indonesia, 3(1), 386-396.

Tambunan, T. S., \& Tambunan, H. (2019). Manajemen Koperasi (L. Malyani \& T. Harimurti (eds.)). Bandung :Yrama Widya. 